\title{
Barriers to the Use of Breast Cancer Risk Reduction Therapies
}

\author{
Arvind Bambhroliya, MBBS, MPH ${ }^{\mathrm{a}}$; Mariana Chavez-MacGregor, MD, MSc ${ }^{\mathrm{b}}$; and \\ Abenaa M. Brewster, MD, MHS
}

\begin{abstract}
Evidence from randomized clinical trials supports the use of tamoxifen, raloxifene, exemestane, and anastrozole for the reduction of risk of invasive breast cancer, predominately estrogen receptorpositive tumors. Revised clinical guidelines now strongly recommend that physicians offer high-risk women medication for breast cancer risk reduction. Although only a small portion of eligible women receive risk reduction medication, evidence suggests higher acceptance among women with atypical hyperplasia or lobular carcinoma in situ. Among physicians, barriers for prescribing risk reduction medications include inadequate training in risk assessment, lack of reimbursement for prevention counseling, and the unavailability of easily accessible and user-friendly prediction tools for estimating risk/benefit profiles. Strategies to improve uptake among women have focused on providing education about breast cancer risk and information that accurately conveys the risks and benefits of risk reduction medications. Priority areas of research that have been identified to improve the use of risk reduction medications are the (1) development of risk assessment tools that more accurately identify women most likely to benefit, (2) identification of circulating or tissue biomarkers that can predict and monitor responsiveness of treatment, and (3) better understanding of patient-related barriers, including patients' subjective beliefs and experiences. (J Natl Compr Canc Netw 2015;13:927-935)
\end{abstract}

\section{NCCN: Continuing Education}

\section{Accreditation Statement}

This activity has been designated to meet the educational needs of physicians and nurses involved in the management of patients with cancer. There is no fee for this article. No commercial support was received for this article. The National Comprehensive Cancer Network

From the Departments of a Clinical Cancer Prevention and b ${ }^{b}$ ealth Services Research, The University of Texas MD Anderson Cancer Center, Houston, Texas.

Submitted March 30, 2015; accepted for publication May 18, 2015.

Dr. Chavez-MacGregor has disclosed that she receives institutional research support from Novartis, and is a consultant for Pfizer and Invitae. The remaining authors have disclosed that they have no financial interests, arrangements, affiliations, or commercial interests with the manufacturers of any products discussed in this article or their competitors.

Correspondence: Abenaa M. Brewster, MD, MHS, The University of Texas MD Anderson Cancer Center, 1515 Holcombe Boulevard, Department of Clinical Cancer Prevention, Unit Number 1360, Houston, TX 77230-1439. E-mail: abrewster@mdanderson.org
(NCCN) is accredited by the ACCME to provide continuing medical education for physicians.

NCCN designates this journal-based CME activity for a maximum of 1.0 AMA PRA Category 1 Credit $^{\mathrm{TM}}$. Physicians should claim only the credit commensurate with the extent of their participation in the activity.

NCCN is accredited as a provider of continuing nursing education by the American Nurses Credentialing Center's Commission on Accreditation.

NCCN designates this educational activity for a maximum of 1.0 contact hour. Accreditation as a provider refers to recognition of educational activities only; accredited status does not imply endorsement by NCCN or ANCC of any commercial products discussed/displayed in conjunction with the educational activity. Kristina M. Gregory, RN, MSN, OCN, is our nurse planner for this educational activity.

All clinicians completing this activity will be issued a certificate of participation. To participate in this journal CE activity: 1) review the learning objectives and author disclosures; 2) study the education content; 3 ) take the posttest with a $66 \%$ minimum passing score and complete the evaluation at http://education.nccn.org/ node/70206; and 4) view/print certificate.

Release date: July 9, 2015; Expiration date: July 9, 2016

\section{Learning Objectives}

Upon completion of this activity, participants will be able to:

- Understand the barriers clinicians face for prescribing breast cancer risk reduction medications

- Explain several strategies to educate women on breast cancer risk and risk reduction strategies

- Identify research areas to improve the use of risk reduction medication for women who are at high risk for breast cancer

\section{EDITOR}

Kerrin M. Green, MA, Assistant Managing Editor, JNCCN—Journal of the National Comprehensive Cancer Network

Ms. Green has disclosed that she has no relevant financial relationships.

\section{CE AUTHORS}

Deborah J. Moonan, RN, BSN, Director, Continuing Education, has disclosed that she has no relevant financial relationships.

Ann Gianola, MA, Manager, Continuing Education Accreditation \& Program Operations, has disclosed that she has no relevant financial relationships.

Kristina M. Gregory, RN, MSN, OCN, Vice President, Clinical Information Operations, has disclosed that she has no relevant financial relationships. Rashmi Kumar, PhD, Senior Manager, Clinical Content, has disclosed that she has no relevant financial relationships. 


\section{Evidence for Risk Reduction Therapies for Invasive Breast Cancer}

Several randomized clinical trials have provided evidence for the efficacy of selective estrogen receptor modulators (SERMs) for the primary prevention of invasive breast cancer. ${ }^{1-5}$ The Breast Cancer Prevention Trial (BCPT) enrolled women based on either age of 60 years or older, or age 35 to 59 years with a modified Gail model 5-year predicted risk of breast cancer of $1.66 \%$ or greater or a history of lobular carcinoma in situ (LCIS). BCPT randomized women to receive tamoxifen or placebo, and results showed that the tamoxifen arm had a significant reduction in the risk of developing an estrogen receptor (ER)-positive tumor (relative risk [RR], 0.38; 95\% CI, 0.28-0.50), and had no risk reduction benefit for ER-negative tumors (RR, 1.31; 95\% CI, 0.86-2.01). ${ }^{1}$ Tamoxifen was associated with a 2.5-fold increased risk of endometrial carcinoma and an increased risk of thromboembolic events and cataracts. ${ }^{1}$ The European randomized trials of tamoxifen compared with placebo demonstrated a more modest benefit of tamoxifen (39\%-22\%) for reducing the risk of ER-positive tumors. ${ }^{2-4}$

The initial results of the Study of Tamoxifen and Raloxifene (STAR) trial after 47 months of follow-up demonstrated that raloxifene was as effective as tamoxifen in reducing the overall risk of breast cancer (RR, 1.02; 95\% CI, 0.82-1.28) and ER-positive tumors (RR, 0.93; 95\% CI, 0.72-1.24) in high-risk postmenopausal women. The raloxifene arm experienced fewer adverse events, including thromboembolic events, endometrial cancer, and cataracts. ${ }^{5}$ Similar risks between the treatment arms were seen for ischemic heart disease, fractures, and stroke. With a longer median follow-up time of 81 months, raloxifene has proven to be $76 \%$ as effective as tamoxifen in reducing the overall risk of invasive breast cancer (RR, 1.24; 95\% CI, 1.05-1.47). ${ }^{6}$

Two aromatase inhibitors have been investigated for the primary prevention of breast cancer. MAP.3 was a randomized placebo-controlled trial designed to investigate the use of exemestane for the primary prevention of invasive breast cancer. The study included a postmenopausal population that was similar to the one studied in the BCPT and STAR trials. At a median follow-up of 35 months, exemestane reduced the overall risk of breast cancer (RR, 0.35; 95\% CI, 0.18-0.70), ER-positive tumors (RR, 0.27; 95\% CI, $0.12-0.60$ ), and ER-negative tumors (RR, 0.80; $95 \%$ CI, 0.21-2.98) compared with placebo. ${ }^{7}$ Arthritis and hot flashes, but not osteoporosis or clinical fractures, were more frequent in the exemestane arm. Another phase III trial, IBIS-II, randomized 3864 high-risk postmenopausal women to receive either placebo or anastrozole. ${ }^{8}$ At a median follow-up of 60 months, a statistically significant reduction of $50 \%$ was seen in the overall risk of developing invasive breast cancer, and a 58\% reduction in the risk of developing ER-positive tumors among women assigned to the anastrozole arm. Musculoskeletal adverse events, vasomotor symptoms, dry eyes, and hypertension were reported more frequently among women in the anastrozole group than in those in the placebo arm. No significant differences were observed in the frequency of thromboembolic events, cerebrovascular events, or myocardial infarction. Tamoxifen and raloxifene are the only 2 risk reduction medications approved by the FDA for breast cancer prevention.

\section{Guidelines for Breast Cancer Risk Reduction Therapies}

In 2013, the US Preventive Services Task Force (USPSTF) reaffirmed its 2002 recommendation for the use of breast cancer risk reduction medications. The recommendation states that clinicians should engage in shared, informed decision-making with women at an increased risk for breast cancer regarding medications to reduce this risk. Furthermore, clinicians should offer to prescribe tamoxifen or raloxifene for those at an increased risk for breast cancer and at low risk for adverse medication effects (B recommendation). ${ }^{9}$ Based on the Freedman et $\mathrm{al}^{10}$ risk-benefit tables for women aged 50 years and older, the task force concluded that most women with a 5 -year risk of breast cancer of $3.0 \%$ or greater would be expected to have greater benefit than harm. The $\mathrm{B}$ recommendation did not include women with a history of ductal carcinoma in situ or LCIS. ${ }^{9}$

In July 2013, ASCO updated its clinical practice guidelines on the use of tamoxifen, raloxifene, or exemestane for breast cancer risk reduction. ${ }^{11} \mathrm{~A}$ stronger recommendation was issued for risk reduction medication and instead of stating "may be offered," the language was modified to "should be discussed as an option." The ASCO guidelines define high-risk women as those with a 5 -year risk of $1.66 \%$ or greater or those with LCIS.

A recommendation for the use of tamoxifen and raloxifene is also supported by NCCN. ${ }^{12}$ Based on 
the results of the MAP.3 trial and the IBIS-II trial, both exemestane and anastrozole were included as choices for breast cancer prevention. The NCCN recommendation for exemestane and anastrozole was limited to postmenopausal women aged 35 years or older with a modified Gail model 5-year risk of $1.7 \%$ or more, or a history of LCIS (Table 1$).{ }^{12}$

\section{Uptake of Breast Cancer Risk Reduction Therapies in the United States}

Despite more than a decade of scientific evidence demonstrating the clinical benefit associated with the use of risk reduction medications, population-based estimates in the United States indicate that the uptake of tamoxifen and raloxifene has remained low. Waters et $\mathrm{al}^{13}$ used data from the National Health Interview Survey and projected that $0.03 \%(n=20,598)$ and $0.2 \%(n=96,890)$ of eligible women in the United States used tamoxifen or raloxifene, respectively, in 2010. This contrasts with estimates that there are approximately 2 million women in the United States for whom the benefits would be expected to outweigh the risks. ${ }^{14}$ Nicholas et $\mathrm{a}^{15}$ examined tamoxifen uptake for breast cancer prevention within The Sister Study, a cohort of 50,884 US and Puerto Rican women aged 35 to 74 years enrolled between 2003 and 2009. The study found that 1046 of 50,884 participants (2\%) reported ever using tamoxifen. ${ }^{15}$

Whether women seen in high-risk clinical settings are more motivated to use risk reduction medications has not been well described; published studies are listed in Table 2. In a comprehensive review of 5 studies that reported on the use tamoxifen or raloxifene for breast cancer prevention among women seen in the high-risk clinical setting, the mean uptake was $14.8 \%$ (range, $0.5 \%-51.0 \%$ ), and the largest study consisted of 162 women. ${ }^{16}$ One of these studies ${ }^{17}$ evaluated uptake in high-risk women who initially refused tamoxifen and then were offered it again after the disclosure of their random periareolar fine-needle aspiration results. This study found that the uptake rate was $0 \%$ ( 0 of 51 ) in women found to have nonproliferative or hyperplastic cytology, $7 \%$ ( 2 of 30$)$ in women with borderline atypia, and $50 \%$ (9 of 18) among women with atypia. Other studies ${ }^{18-25}$ not included in the previous review have shown varied uptake rates in the high-risk setting ranging from $2.0 \%$ to $54.4 \%$. In the study that re- ported the lowest uptake rate of $2.0 \%,{ }^{21}$ most of the high-risk consultations (85\%) were conducted by primary care providers (PCPs). The study that reported the highest uptake rate of $54.4 \%$ evaluated acceptance of risk reduction medications at a breast surveillance clinic that provided comprehensive risk assessment and counseling. ${ }^{24}$ Aktas et $\mathrm{al}^{25}$ found that the use of risk reduction medication among eligible postmenopausal women was 23\% (2\% for tamoxifen, $14 \%$ for raloxifene, and $7 \%$ for exemestane). Among 2459 women with a diagnosis of atypia in 1999 or later who received care at 1 of 3 hospitals in Boston, the overall uptake of risk reduction medication was $18.9 \%$, with the highest uptake among women with LCIS $(33.4 \%)$ or severe atypia $(40.8 \%) .{ }^{26}$ Because this study was based on a systematic retrieval of pathology reports, the specific clinical settings in which the women were seen are unknown. However, the results are consistent with previous evidence demonstrating that use of risk reduction medication is more acceptable among women with a high-risk benign breast lesion ${ }^{15,23,27}$; these women are also the ones who have the greatest risk reduction (86\%) with the use of tamoxifen. ${ }^{1}$

The uptake of risk reduction medications has not been studied extensively in the primary care setting. Armstrong et al $^{28}$ surveyed 350 PCPs between 2002 and 2004 and found that only 27\% had prescribed tamoxifen for breast cancer prevention. Corbelli et $\mathrm{al}^{29}$ assessed the frequency of prescribing risk reduction medications for breast cancer among providers across primary care specialties. They found that only $13 \%$ reported having recommended or prescribed preventive medication ( $9 \%$ internal medicine, $8 \%$ family medicine, $30 \%$ gynecology).

\section{Physician Barriers to Prescribing Breast Cancer Risk Reduction Therapies}

Typically, the first interaction high-risk women have with physicians is in the primary care setting; therefore, PCPs play a pivotal role in the implementation of various methods of breast cancer risk reduction. A significant barrier faced by PCPs in prescribing risk reduction medications is the difficulty in identifying women who would be eligible to receive treatment. In a community cohort, Brewster et $\mathrm{al}^{30}$ evaluated the prevalence of women for whom the benefits would outweigh the risks of tamoxifen for risk reduction. They found that a PCP 
Table 1 Summary of Recommendations for Use of Chemopreventive Agents for Breast Cancer Risk Reduction by Major Guidelines

\begin{tabular}{|c|c|c|c|}
\hline & $\begin{array}{l}\text { US Preventive Service Task Force } \\
\text { Moyer }\end{array}$ & $\begin{array}{l}\text { ASCO } \\
\text { Visvanathan et al }{ }^{11}\end{array}$ & $\begin{array}{l}\text { NCCN } \\
\text { Bevers et al }{ }^{12}\end{array}$ \\
\hline Population & $\begin{array}{l}\text { Asymptomatic women aged } \geq 35 \\
\text { y; with no prior diagnosis of } B C \text {, } \\
\text { DCIS, or LCIS; and at increased } \\
\text { risk for BC }\end{array}$ & $\begin{array}{l}\text { Women with no personal } \\
\text { history of } \mathrm{BC} \text { and at } \\
\text { increased risk of developing } \\
\mathrm{BC} \text {, defined as those with a } \\
5 \text {-y projected absolute risk } \\
\text { of } \geq 1.66 \% \text { (based on the } \mathrm{NCl} \\
\mathrm{BC} \text { Risk Assessment Tool or } \\
\text { an equivalent measure) or } \\
\text { women diagnosed with LCIS }\end{array}$ & $\begin{array}{l}\text { Healthy premenopausal and } \\
\text { postmenopausal women aged } \geq 35 \\
y \text {, whose life expectancy is } \geq 10 y \text {, } \\
\text { and have } a \geq 1.7 \% 5 \text {-y risk for } B C \text { as } \\
\text { determined by the modified Gail } \\
\text { model, or who with prior thoracic } \\
\text { radiation }<30 \text { y of age or history of } \\
\text { LCIS or ADH }\end{array}$ \\
\hline \multirow[t]{9}{*}{ Risk assessment } & \multirow{2}{*}{$\begin{array}{l}\text { Not any one particular risk } \\
\text { prediction model is endorsed }\end{array}$} & - Gail model & \multirow{3}{*}{$\begin{array}{l}\text { - Risk models that are } \mathrm{NCl} \text { Breast } \\
\text { Cancer Risk Assessment Tool } \\
\text { (http://www.cancer.gov/bcrisktool) }\end{array}$} \\
\hline & & \multirow{5}{*}{$\begin{array}{l}\text { - NCI Breast Cancer Risk } \\
\text { Assessment Tool (http:// } \\
\text { www.cancer.gov/ } \\
\text { bcrisktool) } \\
\text { - Other validated models } \\
\text { (including Tyrer-Cuzick }{ }^{56} \text { ) }\end{array}$} & \\
\hline & Clinicians can use any of & & \\
\hline & following tools: & & \multirow{6}{*}{$\begin{array}{l}\text { - Other risk assessment models for } \\
\text { women with strong family history } \\
\text { of BC or ovarian cancer (Claus, } \\
\text { BRCAPRO, Tyrer-Cuzick, and } \\
\text { BOADICEA) }\end{array}$} \\
\hline & - NCl Breast Cancer Risk & & \\
\hline & $\begin{array}{l}\text { Assessment Tool } \\
\text { (www.cancer.gov/bcrisktool) }\end{array}$ & & \\
\hline & $\begin{array}{l}\text { - Breast Cancer Surveillance } \\
\text { Consortium model (https:// } \\
\text { tools.bcsc-scc.org/BC5yearRisk) }\end{array}$ & \multirow[t]{3}{*}{$\begin{array}{l}\text { Eligibility criteria } \\
\text { used in the various BC } \\
\text { chemoprevention trials }\end{array}$} & \\
\hline & $\begin{array}{l}\text { - Other risk assessment models } \\
\text { developed Rosner and } \\
\text { Colditz, }{ }^{54} \text { Chlebowski, }{ }^{55} \text { Tyrer } \\
\text { and Cuzick, }{ }^{56} \text { and others }\end{array}$ & & \\
\hline & $\begin{array}{l}\text { There is no single cutoff for } \\
\text { defining increased risk }\end{array}$ & & \\
\hline \multirow[t]{3}{*}{ Recommendations } & \multirow{3}{*}{$\begin{array}{l}\text { Clinicians should offer to } \\
\text { prescribe risk reducing } \\
\text { medications, such as tamoxifen } \\
\text { or raloxifene, for asymptomatic } \\
\text { women; aged } \geq 35 \mathrm{y} \text {; with no } \\
\text { prior diagnosis of } \mathrm{BC} \text {, DCIS, } \\
\text { or LCIS; and at increased risk } \\
\text { for BC and at low risk for } \\
\text { adverse medication effects (B } \\
\text { recommendation) }\end{array}$} & \multirow{3}{*}{$\begin{array}{l}\text { Tamoxifen ( } 20 \mathrm{mg} / \mathrm{d} \text { for } 5 \mathrm{y} \text { ) } \\
\text { should be discussed as an } \\
\text { option to reduce the risk of } \\
\text { ER-positive BC in women at } \\
\text { increased risk of BC aged } \\
\geq 35 \mathrm{y} \\
\text { Raloxifene ( } 60 \mathrm{mg} / \mathrm{d} \text { for } \\
5 \mathrm{y} \text { ) and exemestane ( } 25 \\
\mathrm{mg} / \mathrm{d} \text { for } 5 \mathrm{y} \text { ) should also } \\
\text { be discussed as options } \\
\text { for BC risk reduction in } \\
\text { postmenopausal women }\end{array}$} & \multirow{2}{*}{$\begin{array}{l}\text { Category } 1 \text { recommendation } \\
\text { as an option to reduce } B C \text { risk } \\
\text { in healthy premenopausal and } \\
\text { postmenopausal women aged } \geq 35 y, \\
\text { whose life expectancy is } \geq 10 \mathrm{y} \text {, and } \\
\text { who have a } \geq 1.7 \% 5 \text {-y risk for } B C \\
\text { as determined by the modified Gail } \\
\text { model, or who with prior thoracic } \\
\text { radiation aged }<30 \text { y or history of } \\
\text { LCIS or } A D H\end{array}$} \\
\hline & & & \\
\hline & & & $\begin{array}{l}\text { Category } 1 \text { recommendation is for } \\
\text { use of raloxifene, } \mathrm{Al} \text { (exemestane } \\
\text { and anastrozole) to reduce } \mathrm{BC} \text { risk is } \\
\text { limited to healthy postmenopausal } \\
\text { women aged } \geq 35 \text { y who have a } \\
\geq 1.7 \% \text {-y risk for } \mathrm{BC} \text { as determined } \\
\text { by the modified Gail model, or who } \\
\text { have had prior thoracic radiation }<30 \\
\text { y of age or history of LCIS or ADH }\end{array}$ \\
\hline
\end{tabular}

Abbreviations: ADH, atypical ductal hyperplasia; Al, aromatase inhibitor; BC, breast cancer; DCIS, ductal carcinoma in situ; ER, estrogen receptor; LCIS, lobular carcinoma in situ.

would need to screen 26 women aged 40 to 49 years and 142 women aged 60 to 70 years with a uterus using the modified Gail model to find 1 women who would eligible for counseling and have a favorable risk/benefit ratio with tamoxifen. ${ }^{30}$ Corbelli et $\mathrm{al}^{29}$ assessed the frequency of use of the Gail model among providers across primary care specialties. They found that only $40 \%$ of provid- ers reported having used the Gail model (37\% internal medicine, 33\% family medicine, $60 \%$ gynecology), and the most commonly cited barriers for its use were lack of time and familiarity. Only approximately 15\% and $9 \%$ of PCPs, reported by Armstrong et $\mathrm{a}^{28}$ and Sabatino et $\mathrm{al},{ }^{31}$ respectively, felt confident about using Gail risk scores to identify high-risk women. 


\section{Table 2 Studies That Evaluated Real Uptake Rates of Breast Cancer Risk Reduction Medications in} the High-Risk Clinical Setting

\begin{tabular}{|c|c|c|c|c|}
\hline Study & Number of Participants & Clinic Type & $\begin{array}{l}\text { High- } \\
\text { Risk } \\
\text { Setting }\end{array}$ & Uptake of Risk Reduction Medication \\
\hline $\begin{array}{l}\text { Port et al, } \\
2001\end{array}$ & 43 & $\begin{array}{l}\text { Surgical Oncology Department } \\
\text { at Memorial Sloan Kettering } \\
\text { Special Surveillance Breast } \\
\text { Program }\end{array}$ & Yes & $4.7 \%(2 / 43)$ for tamoxifen \\
\hline $\begin{array}{l}\text { Bober et al, } \\
2004\end{array}$ & 129 & $\begin{array}{l}\text { Cancer Risk and Prevention } \\
\text { program at Beth Israel } \\
\text { Deaconess Medical Center, } \\
\text { STAR or P-2 Trial, } \\
\text { Oncological practice }\end{array}$ & Yes & $\begin{array}{l}2 \text { mo: } \\
28.7 \%(37 / 129 \text { opted to take } \\
\text { tamoxifen) }+27.1 \% \text { ( } 35 / 129 \text { opted to } \\
\text { enroll into the STAR trial) } \\
4 \text { mo: } \\
25.6 \%(33 / 129 \text { were on tamoxifen })+ \\
25.6 \% \text { (33/129 were STAR participants) }\end{array}$ \\
\hline $\begin{array}{l}\text { Tchou et al, }{ }^{18} \\
2004\end{array}$ & 219 & Lynn Sage Breast Center & Yes & $\begin{array}{l}42 \%(57 / 137) \\
137 / 219 \text { were offered tamoxifen }\end{array}$ \\
\hline $\begin{array}{l}\text { Taylor and } \\
\text { Taguchi, } \\
2005\end{array}$ & 89 & Oncology Referral Center & Yes & $\begin{array}{l}1.1 \%(1 / 89) \text { for tamoxifen } \\
6.7 \%(6 / 89) \text { for raloxifene }\end{array}$ \\
\hline $\begin{array}{l}\text { Goldenberg } \\
\text { et al, }{ }^{17} 2007\end{array}$ & 99 & $\begin{array}{l}\text { Duke University Medical } \\
\text { Center }\end{array}$ & Yes & $\begin{array}{l}\text { Initially: } 0 \%(0 / 99) \\
\text { Within } 3 \mathrm{mo} \text {, post-RPFNA biomarker } \\
\text { analysis: } 0 \%(0 / 51) \text { for nonproliferative } \\
\text { or hyperplastic cytology } \\
7 \%(2 / 30) \text { for borderline atypia } \\
50 \%(9 / 18) \text { for atypia }\end{array}$ \\
\hline $\begin{array}{l}\text { Fagerlin et } \\
\text { al, }^{40} 2010\end{array}$ & 632 & $\begin{array}{l}\text { Henry Ford Health System, } \\
\text { Michigan } \\
\text { Group Health, Washington }\end{array}$ & $\begin{array}{l}\text { Not } \\
\text { specified }\end{array}$ & $\begin{array}{l}0.5 \%(3 / 632) \text { at } 3 \mathrm{mo} \\
\text { Participants received an online } \\
\text { individually tailored decision aid }\end{array}$ \\
\hline $\begin{array}{l}\text { Layeequr et } \\
\text { al, }{ }^{19} 2009\end{array}$ & 105 & $\begin{array}{l}\text { University-based high-risk } \\
\text { breast clinic }\end{array}$ & Yes & $\begin{array}{l}31.3 \%(15 / 48) \\
48 \text { of } 105 \text { were offered tamoxifen based } \\
\text { on eligibility and contraindications }\end{array}$ \\
\hline $\begin{array}{l}\text { Oppong and } \\
\text { King, }^{20} 2011\end{array}$ & 998 & $\begin{array}{l}\text { Surgical Oncology Department } \\
\text { at Memorial Sloan Kettering } \\
\text { Cancer Center }\end{array}$ & Yes & $\begin{array}{l}16.0 \%(163 / 998) \text { for LCIS surveillance } \\
\text { population } \\
120(74 \%) \text { used tamoxifen, } 55(34 \%) \text { used } \\
\text { raloxifene, and } 3 \text { used anastrozole (a } \\
\text { small number used }>1 \text { agent) }\end{array}$ \\
\hline $\begin{array}{l}\text { Owens et al, } \\
2011\end{array}$ & 868 & Aurora Health Care, Wisconsin & Mixed & $\begin{array}{l}2.0 \%(17 / 868) \\
85 \% \text { of high-risk consultations were } \\
\text { performed by primary care providers and } \\
15 \% \text { were referred to the breast center }\end{array}$ \\
\hline $\begin{array}{l}\text { Coopey et al, } \\
2012\end{array}$ & $\begin{array}{l}2459 \text { (patients diagnosed } \\
\text { with atypia in } 1999 \text { and } \\
\text { beyond) }\end{array}$ & $\begin{array}{l}\text { Massachusetts General } \\
\text { Hospital Brigham and } \\
\text { Women's Hospital } \\
\text { Newton Wellesley Hospital }\end{array}$ & $\begin{array}{l}\text { Not } \\
\text { specified }\end{array}$ & $\begin{array}{l}18.9 \%(466 / 2459) \text { for overall uptake } \\
33.4 \%(125 / 374) \text { for LCIS } \\
40.8 \%(97 / 238) \text { for severe atypia }\end{array}$ \\
\hline $\begin{array}{l}\text { Razzaboni et } \\
\text { al, }^{22} 2013\end{array}$ & $\begin{array}{l}471 \text { (women who were } \\
\text { eligible and who took part } \\
\text { in the informative step) }\end{array}$ & $\begin{array}{l}\text { Modena Familial Breast and } \\
\text { Ovarian Cancer Center, Italy }\end{array}$ & Yes & $\begin{array}{l}29 \%(137 / 471) \\
\text { Participants agreed to participate in the } \\
\text { IBIS II trial }\end{array}$ \\
\hline $\begin{array}{l}\text { Donnelly et } \\
\mathrm{al}^{23} 2014\end{array}$ & 1279 & $\begin{array}{l}\text { Genesis Breast Cancer } \\
\text { Prevention Centre FHC, } \\
\text { United Kingdom }\end{array}$ & Yes & $\begin{array}{l}10.6 \%(136 / 1279) \\
1279 \text { women were eligible for } \\
\text { tamoxifen }\end{array}$ \\
\hline $\begin{array}{l}\text { Roetzheim } \\
\text { et } \text { al, }^{24} 2015\end{array}$ & $\begin{array}{l}219 \text { (women whose } 5-y \\
\text { risk of breast cancer was } \\
\geq 1.7 \% \text { ) }\end{array}$ & Moffitt Cancer Center & Yes & $\begin{array}{l}54.4 \%(118 / 219 \text { women who accepted a } \\
\text { recommendation and began therapy) } \\
73(61.9 \%) \text { took only tamoxifen, } 34 \\
(28.8 \%) \text { took only raloxifene, and } 11 \\
(9.3 \%) \text { took some combination of the } \\
2 \text { drugs }\end{array}$ \\
\hline $\begin{array}{l}\text { Aktas et } \\
\mathrm{al}^{25} 2015\end{array}$ & 90 & $\begin{array}{l}\text { Yale Breast Cancer } \\
\text { Prevention Clinic }\end{array}$ & Yes & $\begin{array}{l}23 \%(13 / 56) \\
56 \text { of } 90 \text { postmenopausal women were } \\
\text { eligible for chemoprevention } \\
1(7.7 \%) \text { took tamoxifen, } 8(61.5 \%) \\
\text { took raloxifene, and } 4(30.8 \%) \text { took } \\
\text { exemestane }\end{array}$ \\
\hline
\end{tabular}

Abbreviations: LCIS, lobular carcinoma in situ; RPFNA, random periareolar fine need aspiration. 
Additional barriers reported by physicians for not prescribing risk reduction medications include lack of time, ${ }^{31,32}$ insufficient information about risk reduction options, ${ }^{31,32}$ insufficient training in counseling, ${ }^{31,32}$ and insufficient reimbursement. ${ }^{32}$ Armstrong et a ${ }^{28}$ found that PCP prescription of risk reduction medication was strongly associated with patient demand, ease of determining high-risk eligibility, and the belief that the benefits of tamoxifen outweighed the risks. ${ }^{28}$ Interestingly, physician concern about the side effects was not found to be associated with the prescription of risk reduction medications. ${ }^{28}$ These findings suggest that efforts to address logistical factors, such as a quick determination of a woman's eligibility and a tool that can be used to balance the risks and benefits, are needed in the busy primary care setting. To facilitate this process, risk-benefit models for breast cancer risk reduction need to be interactive and available online to both physicians and patients. ${ }^{33}$ In addition, risk-benefit models should incorporate, in a patient-friendly format, additional modeled end points, such as lifetime risk with and without the use of risk reduction medication and the competing risks of treatment-related comorbidities.

Several studies have shown that the higher a woman's risk of breast cancer, the more likely she will be prescribed a risk reduction medication. ${ }^{15,23,27}$ In a survey of oncologists, $73 \%$ reported discussing risk reduction medications with their patients. ${ }^{34}$ Therefore, targeting educational interventions to physicians and surgeons who specialize in risk assessment and counseling and who interact with subsets of women referred to high-risk breast clinics may provide the best opportunity to rapidly improve risk reduction medication use, and ultimately decrease the incidence of breast cancer.

\section{Patient Barriers to Accepting Breast Cancer Risk Reduction Therapies}

Fear and concerns about side effects of treatment are the most common barriers women cite to accepting breast cancer risk reduction medications, ${ }^{35-38}$ and the most feared side effects reported for the SERMs are endometrial cancer and thromboembolic events. ${ }^{36}$ Moreover, most women perceive that their risk of developing these side effects would be $40 \%$ or greater even after they are presented with the balance of risks and benefits. ${ }^{36}$ The toxicity profile of the aromatase inhibitors has been thought to be more acceptable to women than that of the SERMs; however, Aktas et $\mathrm{al}^{25}$ found that the reasons cited by patients for deciding against exemestane were primarily concerns about worsening bone density and vasomotor and arthralgia symptoms.

A higher self-perceived risk of developing breast cancer is positively associated with acceptance of risk reduction medications, ${ }^{35,38}$ and uptake has been shown to be significantly higher among women with a history of atypical hyperplasia or LCIS $17,20,26$ who have a 5-year risk of breast cancer of approximately $6 \% .{ }^{1}$ However, many women have the perception that risk reduction medication will not substantially lower their risk of developing breast cancer. ${ }^{39,40}$ In addition, the lack of a surrogate tissue biomarker of risk may contribute to the lower uptake of risk reduction medication among women who meet eligibility criteria based on family history and reproductive risk factors versus women who have a tissue diagnosis of a high-risk benign breast lesion (eg, atypical ductal hyperplasia or LCIS). ${ }^{41}$

Interestingly, studies assessing the acceptance of risk reduction medications among high-risk women have shown a higher percentage of acceptance among women faced with a hypothetical decision (24.7\%) versus those who actually initiate treatment $(14.8 \%),{ }^{16}$ and the reasons for the discrepancy are multifactorial. Recognition of the importance of a woman's individual beliefs and experiences on her acceptance of risk reduction medication is an emerging area of research. Korfage et $\mathrm{al}^{42}$ reported that $62 \%$ of women enrolled in the control arm of a randomized decision aid intervention study and who did not receive education about risk reduction medication had a negative attitude about treatment. Ralph et $\mathrm{al}^{43}$ examined 107 high-risk women and showed that a significant factor in decisions regarding whether to take SERMs was related to the women's individual beliefs about the benefits and risks of treatment, which may not have been influenced by their physician's recommendation but rather by their experiences, such as knowledge of a relative who may have experienced side effects or developed breast cancer while on treatment. Risk counseling that addresses a woman's subjective feelings of breast cancer risk and beliefs about treatment efficacy is needed.

Cost and health insurance coverage are important factors associated with acceptance of risk reduction medication, particularly among low-income women. ${ }^{39,44}$ The impact of the Accountable Care Act mandate requiring insurance coverage of risk reduc- 


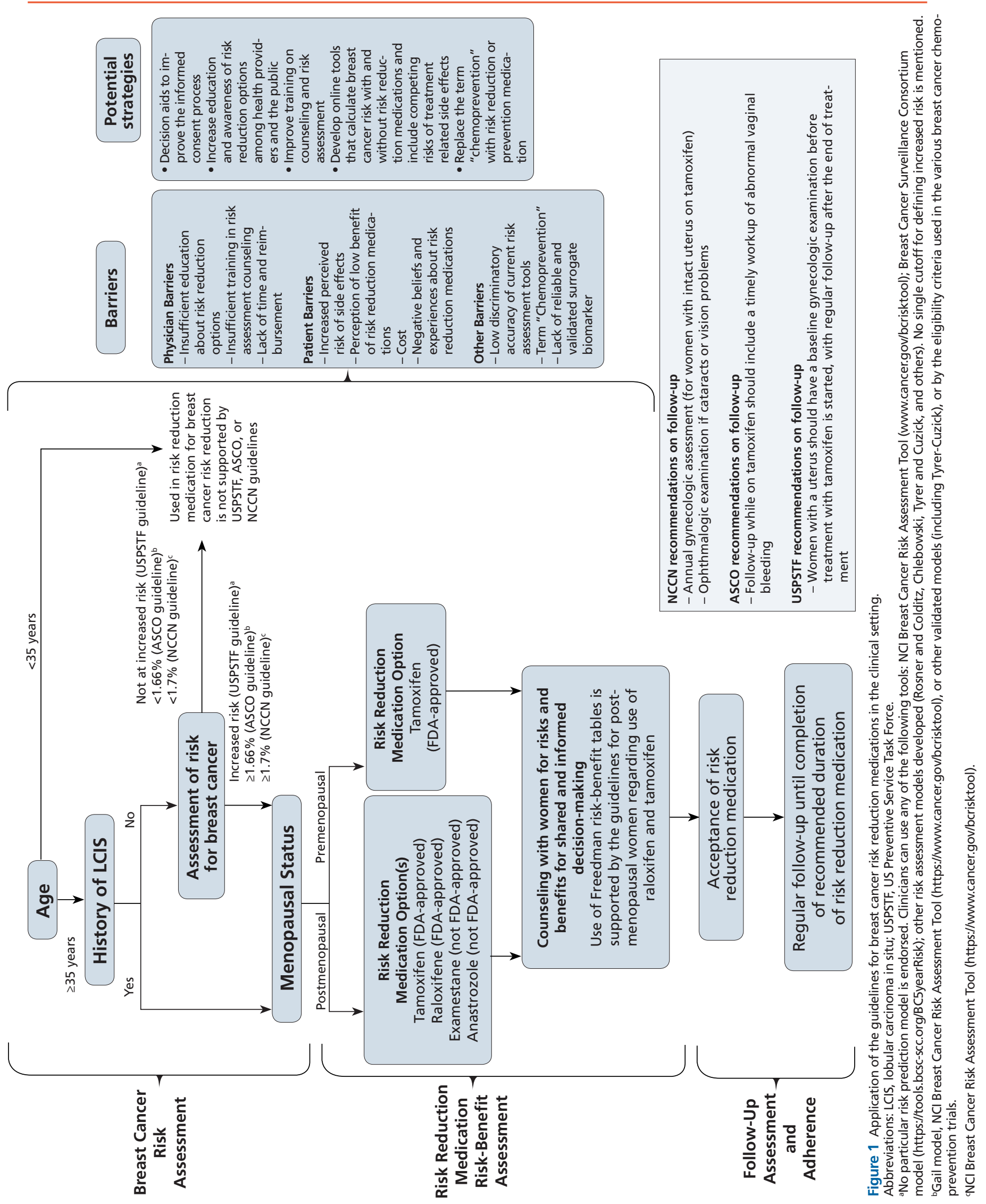


Bambhroliya et al

tion medications (B recommendation by the USPSTF), with no copayment or deductible on the use of tamoxifen or raloxifene, has not yet been determined. ${ }^{5}$ Other studies have found that education and lower income were inversely associated with the use of risk reduction medications. ${ }^{38,45-47}$ Although women who are provided with an educational decision aid about breast cancer prevention were shown to be more likely to make an informed choice, their willingness to take risk reduction medication after receiving a decision aid has been disappointingly low, ranging from $4 \%$ to $6 \%, 48,49$ and the actual uptake rate of risk reduction medication was less than $1 \% .{ }^{49}$ In another randomized trial, Korfage et $\mathrm{al}^{42}$ investigated the impact of an online decision aid on informed intentions and decisions of high-risk women. The authors found that the decision aid increased informed decision-making about risk reduction medication, although the impact on knowledge diminished over time (54\% at posttest to $18 \%$ at 3 -month follow-up).

\section{Conclusions}

Approximately 232,000 women are diagnosed with invasive breast cancer annually in the United States, and most tumors are ER-positive..$^{50,51}$ Although tamoxifen, raloxifene, exemestane, and anastrozole have not been shown to reduce mortality when given in the prevention setting, the benefit despite their treatment-related side effects in reducing breast cancer incidence is a valuable prevention goal. Significant physician- and patient-related barriers are summarized in this article (Figure 1). Other barriers to the use of breast cancer risk reduction medication that need to be addressed include the low discriminatory accuracy of current risk assessment tools in accurately predicting women who will develop breast cancer, ${ }^{52}$ the inability to prospectively identify women at risk for an ER-positive versus ER-negative tumor, and the lack of reliable validated biomarkers to measure preventive drug effectiveness. ${ }^{52}$

\section{References}

1. Fisher B, Costantino JP, Wickerham DL et al. Tamoxifen for prevention of breast cancer: report of the National Surgical Adjuvant Breast and Bowel Project P-1 study. J Natl Cancer Inst 1998;90:1371-1388.

2. Cuzick J, Forbes J, Edwards R, et al. First results from the International Breast Cancer Intervention Study (IBIS-I): a randomised prevention trial. Lancet 2002;360:817-824.
3. Powles T, Eeles R, Ashley S, et al. Interim analysis of the incidence of breast cancer in the Royal Marsden Hospital tamoxifen randomised chemoprevention trial. Lancet 1998;352:98-101.

4. Veronesi U, Maisonneuve P, Costa A, et al. Prevention of breast cancer with tamoxifen: preliminary findings from the Italian randomised trial among hysterectomised women. Lancet 1998;352:93-97.

5. Vogel VG, Constantino JP, Wickerham DL, et al. Effects of tamoxifen vs raloxifene on the risk of developing invasive breast cancer and other disease outcomes: the NSABP Study of Tamoxifen and Raloxifene (STAR) P-2 trial. JAMA 2006;295:2727-2741.

6. Vogel VG, Constantino JP, Wickerham DL, et al. Update of the National Surgical Adjuvant Breast and Bowel Project Study of Tamoxifen and Raloxifene (STAR) P-2 trial: preventing breast cancer. Cancer Prev Res (Phila) 2010;3:696-706.

7. Goss, P.E., et al. Exemestane for breast-cancer prevention in postmenopausal women. N Engl J Med 2011;364:2381-2391.

8. Cuzick J, Sestak I, Forbes JF, et al. Anastrozole for prevention of breast cancer in high-risk postmenopausal women (IBIS-II): an international, double-blind, randomised placebo-controlled trial. Lancet 2014;383:1041-1048.

9. Moyer VA; for the U.S. Preventive Services Task Force. Medications to decrease the risk for breast cancer in women: recommendations from the U.S. Preventive Services Task Force recommendation statement. Ann Intern Med 2013;159:698-708.

10. Freedman AN, Yu B, Gail MH, et al. Benefit/risk assessment for breast cancer chemoprevention with raloxifene or tamoxifen for women age 50 years or older. J Clin Oncol 2011;29:2327-2333.

11. Visvanathan $K$, Hurley $P$, Bantug E, et al. Use of pharmacologic interventions for breast cancer risk reduction: American Society of Clinical Oncology clinical practice guideline. J Clin Oncol 2013;31:2942-2962.

12. Bevers TB, Ward JH, Arun BK, et al. NCCN Clinical Practice Guidelines in Oncology: Breast Cancer Risk Reduction. Version 1, 2015. Available at: NCCN.org. Accessed June 8, 2015.

13. Waters EA, McNeel TS, Stevens WM, Freedman AN. Use of tamoxifen and raloxifene for breast cancer chemoprevention in 2010. Breast Cancer Res Treat 2012;134:875-880.

14. Freedman AN, Graubard BI, Rao SR, et al. Estimates of the number of US women who could benefit from tamoxifen for breast cancer chemoprevention. J Natl Cancer Inst 2003;95:526-532.

15. Nichols HB, DeRoo LA, Scharf DR, Sandler DP. Risk-benefit profiles of women using tamoxifen for chemoprevention. J Natl Cancer Inst 2015;107:354.

16. Ropka ME, Keim J, Philbrick JT. Patient decisions about breast cancer chemoprevention: a systematic review and meta-analysis. J Clin Oncol 2010;28:3090-3095.

17. Goldenberg VK, Seewaldt VL, Scott V, et al. Atypia in random periareolar fineneedle aspiration affects the decision of women at high risk to take tamoxifen for breast cancer chemoprevention. Cancer Epidemiol Biomarkers Prev 2007; 16:1032-1034.

18. TchouJ,HouN, Rademaker A, etal. Acceptance of tamoxifen chemoprevention by physicians and women at risk. Cancer 2004;100:1800-1806.

19. Layeequr Rahman $R$, Crawford $S$. Chemoprevention Indication Score: a userfriendly tool for prevention of breast cancer - pilot analysis. Breast 2009;18:289293.

20. Oppong BA, King TA. Recommendations for women with lobular carcinoma in situ (LCIS). Oncology (Williston Park) 2011;25:1051-1058.

21. Owens WL, Gallagher TJ, Kincheloe MJ, Ruetten VL. Implementation in a large health system of a program to identify women at high risk for breast cancer. J Oncol Pract 2011;7:85-88.

22. Razzaboni E, Toss A, Cortesi L, et al. Acceptability and adherence in a chemoprevention trial among women at increased risk for breast cancer attending the Modena Familial Breast and Ovarian Cancer Center (Italy) Breast J 2013;19:10-21.

23. Donnelly LS, Evans DG, Wiseman J, et al. Uptake of tamoxifen in consecutive premenopausal women under surveillance in a high-risk breast cancer clinic. $\mathrm{Br}$ J Cancer 2014;110:1681-1687.

24. Roetzheim RG, Lee JH, Fulp W, et al. Acceptance and adherence to chemoprevention among women at increased risk of breast cancer. Breast 2015;24:51-56.

25. Aktas B, Sorkin M, Pusztai L, Hofstatter EW. Uptake of exemestane chemoprevention in postmenopausal women at increased risk for breast cancer [published online ahead of print February 26, 2015]. Eur J Cancer Prev, in press.

26. Coopey SB, Mazzola E, Buckley JM, et al. The role of chemoprevention in modifying the risk of breast cancer in women with atypical breast lesions. Breast Cancer Res Treat 2012;136:627-633.

27. Runowicz CD, Costantino JP, Wickerham DL, et al. Gynecologic conditions in participants in the NSABP breast cancer prevention study of tamoxifen and raloxifene (STAR). Am J Obstet Gynecol 2011;205:535.e1-5. 
Breast Cancer Risk Reduction Therapies

28. Armstrong K, Quistberg DA, Micco E, et al. Prescription of tamoxifen for breast cancer prevention by primary care physicians. Arch Intern Med 2006; 166:2260-2265.

29. Corbelli J, Borrero S, Bonnema R, et al. Use of the Gail model and breast cancer preventive therapy among three primary care specialties. J Womens Health (Larchmt) 2014;23:746-752.

30. Brewster AM, Christo DK, Lai H, Helzlsouer K. Breast carcinom chemoprevention in the community setting. Estimating risks and benefits. Cancer 2005; 15:1147-1153.

31. Sabatino SA, McCarthy EP, Phillips RS, Burns RB. Breast cancer risk assessment and management in primary care: provider attitudes, practices, and barriers. Cancer Detect Prev 2007;31:375-383.

32. Kaplan CP, Haas JS, Perez-Stable EJ, et al. Factors affecting breast cancer risk reduction practices among California physicians. Prev Med 2005;41:7-15.

33. Ravdin PM. The lack, need, and opportunities for decision-making and informational tools to educate primary-care physicians and women about breast cancer chemoprevention. Cancer Prev Res (Phila) 2010;3:686-688.

34. American Society of Clinical Oncology; Ganz PA, Kwan L, et al. The role of prevention in oncology practice: results from a 2004 survey of American Society of Clinical Oncology members. J Clin Oncol 2006;24:2948-2957.

35. Bober SL, Hoke LA, Duda RB, et al. Decision-making about tamoxifen in women at high risk for breast cancer: clinical and psychological factors. J Clin Oncol 2004;22:4951-4957.

36. Port ER, Montgomery LL, Heerdt AS, Borgen PI. Patient reluctance toward tamoxifen use for breast cancer primary prevention. Ann Surg Oncol 2001;8:580-585.

37. Heisey R, Pimlott N, Clemons M, et al. Women's views on chemoprevention of breast cancer: qualitative study. Can Fam Physician 2006;52:624-625.

38. Melnikow J, Paterniti D, Azari R, et al. Preferences of Women Evaluating Risks of Tamoxifen (POWER) study of preferences for tamoxifen for breast cancer risk reduction. Cancer 2005;103:1996-2005.

39. Cyrus-David MS, Strom SS. Chemoprevention of breast cancer with selective estrogen receptor modulators: views from broadly diverse focus groups of women with elevated risk for breast cancer. Psychooncology 2001;10:521-533.

40. Fagerlin A, Zikmund-Fisher BJ, Nair V, et al. Women's decisions regarding tamoxifen for breast cancer prevention: responses to a tailored decision aid. Breast Cancer Res Treat 2010;119:613-620.

41. Temple R. Cancer chemoprevention--the cardiovascular model. Cancer Prev Res (Phila) 2011;4:307-310

42. Korfage IJ, Fuhrel-Forbis A, Ubel PA, et al. Informed choice about breast cancer prevention: randomized controlled trial of an online decision aid intervention. Breast Cancer Research 2013;15:R74.
43. Ralph AF, Ager B, Bell ML, et al. Women's preferences for selective estrogen reuptake modulators: an investigation using protective motivation theory. Patient Educ Couns 2014;96:106-112.

44. Salant T, Ganschow PS, Olopade OI, Lauderdale DS. "Why take it if you don't have anything?" breast cancer risk perceptions and prevention choices at a public hospital. J Gen Intern Med 2006;21:779-785.

45. Fasching PA, von Minckwitz G, Fischer T, et al. The impact of breast cancer awareness and socioeconomic status on willingness to receive breast cancer prevention drugs. Breast Cancer Res Treat 2007;101:95-104

46. Tjia J, Micco E, Armstrong K. Interest in breast cancer chemoprevention among older women. Breast Cancer Res Treat 2008;108:435-453.

47. Ropka ME, Keim J, Philbrick JT. Patient decisions about breast cancer chemoprevention: a systematic review and meta-analysis. J Clin Oncol 2010;28:3090-3095.

48. McKay A, Martin W, Latosinsky S. How should we inform women at higher risk of breast cancer about tamoxifen? An approach with a decision guide. Breast Cancer Res Treat 2005;94:153-159.

49. Fagerlin A, Dillard AJ, Smith DM, et al. Women's interest in taking tamoxifen and raloxifene for breast cancer prevention: response to a tailored decision aid. Breast Cancer Res Treat 2011;127:681-688.

50. DeSantis C, Ma J, Bryan L, Jemal A. Breast cancer statistics, 2013. CA Cancer J Clin 2014;64:52-62.

51. Gleason MX, Mdzinarishvili $T$, Sherman $S$. Breast cancer incidence in black and white women stratified by estrogen and progesterone receptor statuses. PLoS One 2012; 7:e49359.

52. Howell A, Anderson AS, Clarke RB, et al. Risk determination and prevention of breast cancer. Breast Cancer Res 2014;16:446.

53. Meyskens FL Jr, Curt GA, Brenner DE, et al. Regulatory approval of cancer risk-reducing (chemopreventive) drugs: moving what we have learned into the clinic. Cancer Prev Res (Phila) 2011;4:311-323.

54. Colditz GA, Rosner B. Cumulative risk of breast cancer to age 70 years according to risk factor status: data from the Nurses' Health Study. Am J Epidemiol 2000;152:950-964.

55. Chlebowski RT, Anderson GL, Lane DS, et al. Predicting risk of breast cancer in postmenopausal women by hormone receptor status. J Natl Cancer Inst 2007;99:1695-1705.

56. Tyrer J, Duffy SW, Cuzick K. A breast cancer prediction model incorporating familial and personal risk factors. Stat Med 2004;23:1111-1130.

57. Taylor R, Taguchi K. Tamoxifen for breast cancer chemoprevention: low uptake by high-risk women after evaluation of a breast lump. Ann Fam Med 2005;3:242-7.

\section{Instructions for Completion}

To participate in this journal CE activity: 1) review the learning objectives and author disclosures; 2) study the education content; 3 ) take the posttest with a $66 \%$ minimum passing score and complete the evaluation at http://education.ncon.org/ node/70206; and 4) view/print certificate. After reading the article, you should be able to answer the following multiple- choice questions. Credit cannot be obtained for tests completed on paper. You must be a registered user on NCCN.org. If you are not registered on NCCN.org, click on "New Member? Sign up here" link on the left hand side of the Web site to register. Only one answer is correct for each question. Once you successfully answer all posttest questions you will be able to view and/or print your certificate. Software requirements: Internet

\section{Posttest Questions}

1. Which of the following barriers are reported by physicians for not prescribing risk reduction medications to women with high risk of developing breast cancer?
a. Lack of time
b. Difficulty in identifying women who would be eligible to receive medication
c. Insufficient reimbursement for prevention counseling
d. All of the above
e. None of the above

2. Clinicians need to be better educated on patient demand for risk reduction medication, eligibility criteria for women, and beliefs that medications outweigh the risk. Therefore, which of the following strategies is NOT appropriate for educating patients on risk reduction medications?

a. Use an interactive risk-benefit model that is accessible to both patients and clinicians

b. Refer the patient to a psychologist

c. Apply tools that allow clinicians to quickly identify patient eligibility

d. Discuss lifetime risk with and without the use of risk reduction medication

3. True or False: Counseling that addresses a woman's feelings of breast cancer risk and beliefs about treatment efficacy is important. 